\title{
Lipoma arborescens of the knee joint
}

\author{
Bekir Erol, ${ }^{1}$ Selahattin Ozyurek, ${ }^{2}$ Ferhat Guler, ${ }^{3}$ Ozkan Kose ${ }^{3}$
}

'Department of Radiology, Antalya Education and Research Hospital,

Antalya, Turkey

${ }^{2}$ Department of Orthopaedics and Traumatology, Aksaz Military Hosp, Mugla, Turkey ${ }^{3}$ Department of Orthopaedics and Traumatology,

Antalya Education and Research Hospital, Antalya, Turkey

\section{Correspondence to} Dr Selahattin Ozyurek, fsozyurek@yahoo.com

\section{DESCRIPTION}

A 26-year-old woman presented to our orthopaedic clinic with a difficulty in walking, prolonged pain and recurrent swelling in her left knee joint for the previous 2 years. On physical examination, there was no limitation in the range of motion of the knee; however, both flexion and extension were painful. Other findings were normal. In the laboratory findings, erythrocyte sedimentation rate and $\mathrm{C}$ reactive protein were slightly above normal.

MRI revealed effusion and villous thickening with a similar signal as the fat tissue in all sequences of synovial membrane which was more prominent in the suprapatellar of the left knee (figure 1A-D). MRI also demonstrated frond-like projections. These findings were consistent with lipoma arborescens (LA). The synovial mass with villonodular thickening was excised with arthrotomy and synovectomy. Histopathological examination revealed a lesion which formed villous structures and contained synovial epithelium with hyperplastic form and a mature adipose tissue, hence it was reported as LA (figure 2).

LA is a rare, benign lesion characterised by lipomatous villous proliferation of the synovial membrane. Its aetiology is unknown. ${ }^{1}$ Though it occurs in the knee joint most commonly, it may also occur in other joints. LA presents with painless, slowly progressing swelling associated with intermittent joint effusions. ${ }^{2}$ MRI is the best modality to
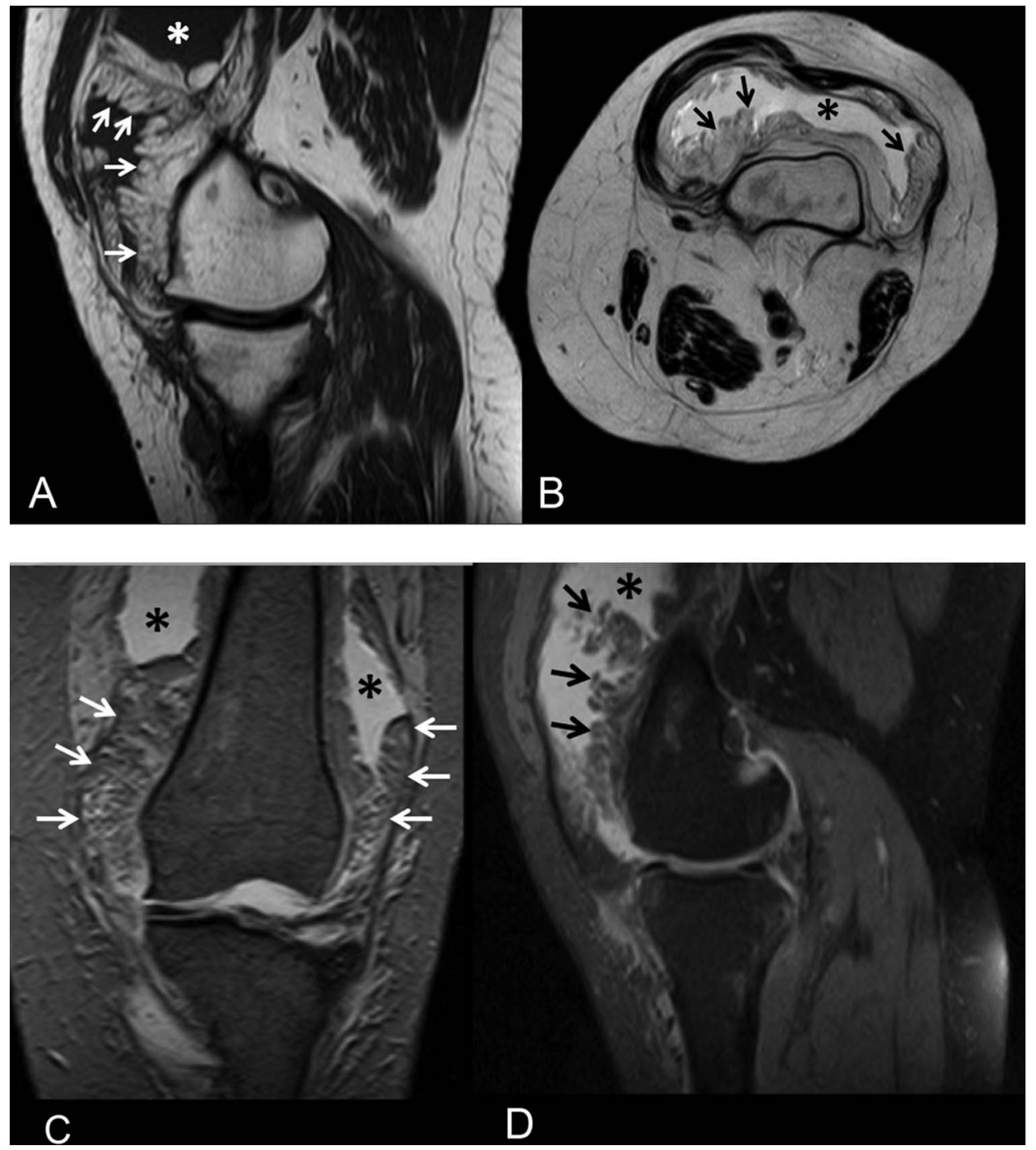

To cite: Erol B, Ozyurek $S$, Guler F, et al. BMJ Case Rep Published online: [please include Day Month Year] doi:10.1136/bcr-2013009271
Figure 1 The lesion structuring villous thickening in synovial membrane (arrows). It demonstrates signal intensity similar to fat tissue in sagittal T1 (A), axial T2 (B) and coronal fat suppressed T2 (C) images. An associating effusion (star) is present in suprapatellar bursa (D). 




Figure 2 The mature adipocyte concentrations in villous structure (H\&Ex20), hyperplasia in the lining epithelium of synovial membrane and mature adipocytes under the epithelium (H\&E $\times 100)$.

diagnose LA. Synovial mass has similar signal intensity as that of fat tissue in all sequences. In addition, MRI easily reveals the frond-like architecture of LA. ${ }^{1}$ Typically, LA is treated by open or arthroscopic synovectomy, and postoperative recurrence is uncommon. ${ }^{1-3}$

\section{Learning points}

- Lipoma arborescens (LA) is a rare, benign lesion characterised by lipomatous villous proliferation of the synovium, predominantly affecting the knee joint. It forms parts of the differential diagnosis for a slowly progressive chronically swollen knee.

- $\mathrm{MRI}$ is the best imaging modality and the cornerstone of the preoperative diagnosis of LA.

- Typically, LA is treated by open or arthroscopic synovectomy, and postoperative recurrence is uncommon.

\section{Competing interests None. \\ Patient consent Obtained.}

Provenance and peer review Not commissioned; externally peer reviewed.

\section{REFERENCES}

1 Nguyen C, Jean-Luc BB, Papelard A, et al. The role of magnetic resonance imaging for the diagnosis of lipoma arborescens in polyarthritic patients with persistent single-joint effusion. J Clin Rheumatol 2009;15:431.

$2 \mathrm{Ji} \mathrm{JH}$, Lee YS, Shafi M. Spontaneous recurrent hemarthrosis of the knee joint in elderly patients with osteoarthritis: an infrequent presentation of synovial lipoma arborescens. Knee Surg Sports Traumatol Arthrosc 2010;18:1352-5.

3 Patil PB, Kamalapur MG, Joshi SK, et al. Lipoma arborescens of knee joint: role of imaging. J Radiol Case Rep 2011;5:17-25.

Copyright 2013 BMJ Publishing Group. All rights reserved. For permission to reuse any of this content visit http://group.bmi.com/group/rights-licensing/permissions.

BMJ Case Report Fellows may re-use this article for personal use and teaching without any further permission.

Become a Fellow of BMJ Case Reports today and you can:

- Submit as many cases as you like

- Enjoy fast sympathetic peer review and rapid publication of accepted articles

- Access all the published articles

- Re-use any of the published material for personal use and teaching without further permission

For information on Institutional Fellowships contact consortiasales@bmjgroup.com

Visit casereports.bmj.com for more articles like this and to become a Fellow 